\title{
Coccyx Fracture
}

National Cancer Institute

\section{Source}

National Cancer Institute. Coccyx Fracture. NCI Thesaurus. Code C26939.

A traumatic break in the coccyx bone. 